Article

\title{
CSR Committees and Their Effect on ESG Performance in UK, France, Germany, and Spain
}

\author{
Elisa Baraibar-Diez *(1) and María D. Odriozola $(1)$ \\ Department of Business Administration, University of Cantabria, 39005 Cantabria, Spain \\ * Correspondence: elisa.baraibar@unican.es
}

Received: 25 June 2019; Accepted: 10 September 2019; Published: 17 September 2019

\begin{abstract}
The multidisciplinary nature of a corporate social responsibility (CSR) committee reflects the commitment as well as the expectations and demands of diverse stakeholders. So far, CSR committees have been mainly considered as variables of control in larger corporate governance models and independent variables that determine CSR or environmental, social, and governance (ESG) disclosure and its reporting quality. However, the effect on corporate performance has been biased to financial performance, so the potential of the analysis of the effect it may have on different facets of non-financial performance has not been exploited. Which it should, since it can be a fundamental tool to achieve sustainability. The objective of this contribution is to test whether companies with a CSR committee not only leads to higher economic scores, but also to higher ESG (environmental, social, governance) scores. To do this, we used regression panel data models in 197 listed firms in Spain, France, Germany, and the UK during the period 2005-2015 including the perspective of European organizations and completing the extant studies in US-based samples. Our results showed that $90 \%$ of companies in the sample had a CSR committee in 2014, and that those companies had significantly different ESG scores than those without a CSR committee. Having a CSR committee also triggered better non-financial performance when considering the four scores and the four countries independently (except for the economic scores in Spain). These results have great implications for practitioners, reflecting the importance of promoting these tools in an organization to enhance non-financial performance and sustainability.
\end{abstract}

Keywords: ESG performance; non-financial performance; sustainability; CSR; CSR committees; ESG; ESG scores

\section{Introduction}

The creation of corporate committees has the purpose of making recommendations to corporate boards and assist board members in their functions. In this advisory role, there are three committees that traditionally guarantee good functioning and independence of the boards, that is, the audit committee, remuneration committee, and nominating committee. As corporate governance bodies, they have been the subject of attention in the literature in recent years [1-4], and their importance has grown since boards are delegating their key functions more and more to those committees. Increasingly, an important part of those functions is related to social responsibility, sustainability, and their impacts on society. Thus, the creation of a CSR committee is, beyond the conviction and commitment of corporate boards on sustainability, one of the first steps that most international standards and guidelines will advise is its implementation to perform a CSR policy. Strong performance in social issues is, as Craig Mackenzie notes, "a source of opportunity to strengthen trust in their brands and to enhance employee motivation" [5] (p. 935). In fact, having a multidisciplinary team that promotes, monitors, and disseminates the socially responsible commitment of the company is a signal to the market [6-8] and to other competitors, as it indicates "an active strategic posture with regards to stakeholder relationships" [8] (p. 125). 
In the academic literature, the study of CSR or sustainability committees has been closely linked to their relationship with corporate governance, especially its role in the board of directors and its interaction with other types of variables (diversity and independence of the board of directors). Therefore, in most cases, research has focused on CSR committees as a corporate governance variable for larger models [1,9-13], mainly related to the disclosure of CSR or ESG information [1,14-19]. In this regard, CSR committees have shown an influence on the volume and quality of CSR information issued by the company, showing its ability to act and decide on sustainability reporting. CSR disclosure is often used as a proxy for CSR implementation [4], but "does not necessarily mean that companies provide the actual performance but the one that the company wants to present to stakeholders" [4] (p. 570). As an entity in itself, CSR committees have been analyzed from the perspective of its composition $[7,20-23]$ as well as from the perspective of its establishment, considering the drivers for the presence of CSR committee [6] in the organization. In the business context, most large companies disclose the presence of a CSR committee in the organization and its importance in the management of social and environmental impacts in their reports. However, the analysis of the impact that these CSR or sustainability committees have on different facets of non-financial performance, preceding the quantity and quality of CSR/ESG/sustainability information disclosure, is underdeveloped. A search in the WoS database using the fields topic "CSR" OR "sustainability" AND "committees" refined by "performance" and "CSR committees" and time span "all years" resulted in 15 records. The number of records was 13 if the search was refined by "disclosure" instead of by "performance".

Some researchers have raised the question of the effectiveness of new board (CSR) committees on achieving compliance with CSR standards [5,7], but there have been fewer attempts to measure the efficiency of turning social strategy into action. However, we must highlight the study of [3] of 100 US companies testing the existence of sustainability committees in economic, environmental, and social sustainability performance; the study of [8] in a US-based sample of companies considered the Best Corporate Citizens over the period 2005-2007; and the study of [7] in a sample of 1742 US companies in the period 2003-2013. Attempts to analyze the effect of sustainability committees on ESG performance in Europe are also limited and differ in their premises. First, the study of [22] focused on the percentage of independent members in the sustainability committee-not the fact of having such a committee - and the likelihood of being included in Dow Jones Sustainability Index (DJSI) Europe. On the other hand, [23] considered the variable CSR committee in their model of corporate governance, but together with other characteristics such as board composition, board diversity, board independence, board size, and board meetings. In this larger model, [23] found that the establishment of a CSR committee positively impacted a bank's ESG performance by using a unique ESG score in a sample of US and European banks.

Thus, the studies proposed so far differ mainly around four main issues: dependent variable (ESG disclosure vs. ESG performance); consideration of CSR committees as independent variables or variables in larger models; the sample (US-based vs European companies); and the use of one or several indicators of ESG. Continuing our previous work [24], in which it was obtained that CSR committees act as control mechanisms, we considered that it was important to give relevance to CSR committees as the main independent variable in achieving non-financial performance. In addition, we followed the lines of work proposed by $[7,8,22,25]$ and also considered different non-financial areas. Thus, the objective of this paper was to analyze whether the presence of a CSR committee affected environmental, social, corporate governance (ESG) and economic performance.

This paper contributes to the literature and practitioners in several ways. First, we contribute to the current literature on corporate governance, especially other corporate governance bodies other than the traditional board committees and their effectiveness in organizational performance. Second, CSR committees "play an important role in assisting the management in CSR strategy formulation and in reviewing the firm's CSR performance" [26] (p. 575), so we wanted to test the efficiency of CSR committees, beyond the support to the board, in increasing ESG scores in the listed companies of four of the largest economies in Europe. This contributes to the knowledge of CSR within the US vs. Europe approach, 
as we were able to compare our results with the studies already carried out in the US. To do this, we advocated the use of disaggregated scores to provide greater insight into the efficiency of CSR committees.

The remainder of this paper is organized as follows. Section 2 includes a framework about the role of CSR committees and its relationship with ESG performance. Section 3 describes the methods of the study. Section 4 includes the results of the empirical research, and Section 5 includes the discussion.

\section{The Role of CSR Committees and Its Effect on ESG Scores}

A CSR committee is usually understood as a subcommittee of the board of directors and can have different names such as "ethics, sustainable development, environment, health and safety, or a public responsibility committee" [20] (p. 1926). Regarding [20], the main characteristics of CSR include the "committee members' experience and knowledge in this field, the responsibility of proposing to the board the CSR policies and strategies to be followed, guaranteeing the proper functioning of CSR information and control systems, and supervision of the annual report" [14] (p. 16). The creation of a CSR committee responds to statements of stakeholder theory, as it implies the creation of governance bodies $[9,27]$ that are able to fulfill stakeholder needs. In addition, the presence of a CSR committee serves as the connection between stakeholder theory and agency theory, as "CSR engagement is a principal-agent relation between managers and shareholders" [12] (p. 55).

CSR engagement and corporate governance are linked in several dimensions. As reviewed by [12], corporate governance can be a pillar for CSR, CSR can be a dimension of corporate governance, and corporate governance and CSR are part of a continuum [27]. For this reason, it is not surprising that corporate governance codes refer to CSR committees. However, these references are not explicit and are mainly included as other board committees.

Principle 23 of the Spanish Governance Code of Listed Companies states that "The membership and organization of any committees established by the board under its powers of self-organization should be similarly configured to those of mandatory committees" [28], and it is especially related to the shared concerns between corporate governance and corporate social responsibility. In the German Corporate Governance Code, there is a recommendation (Recommendation 5.3.) related to the establishment of committees of members with relevant specialist expertise, although there is no reference of CSR committees [29]. The French Corporate Governance code of listed corporations includes no explicit reference to a CSR committee, but includes the areas of social and environmental responsibility as tasks of the board of directors. The UK Corporate Governance Code in 2018 also does not include a reference to the creation of a CSR committee and "more and more boards in the UK seem to be explicitly accepting this role by creating special board committees on CSR" [5] (p. 936). Although not explicitly referred to as CSR committees, Global Reporting Standards (GRI) standards recommend disclosing committees responsible for decision-making on economic, environmental, and social topics in the guideline "Disclosure 102-18". Different approaches of the relationship between corporate governance and CSR may have their origin in the corporate governance system. The UK provides for a one tier board structure as well as Spain, which follows a common law tradition like the UK. Germany requires a two-tier board, whereas French companies can choose between a two-tier or one-tier board structure [30]. In one-tier boards, advantages include "superior flow of information, faster decision-making processes, and better understanding in the business by the boards" [31]. Better integration of the business strategy and decision making between the management and supervision can enhance the creation of a CSR committee when CSR is embedded in the business strategy, but it can also dull some of the effectiveness of the one-tier board. In two-tier boards, the creation of an independent supervisory board responds to monitor the decisions of the management board on behalf of other parties [31]. In two-tier systems, committees are less common when compared to one-tier boards, although large listed companies already have traditional committees such as audit, remuneration, and nomination committees [32]. In this sense, as the supervisory board members represent other members and stakeholders, their functions could overlap some possible functions of the specific CSR committee. 
Although several national corporate governance codes (in both one-tier and two-tier systems) refer to the creation of a CSR committee, very few countries have gone further when legislating on CSR committees. In fact, only India has included the convenience of constituting a CSR committee for certain firms as well as the disclosure of its compositions and tasks in the Companies Act 2013, which regulates the responsibilities of a company, directors, and dissolution of the company. Although legislating on CSR issues may clash with the voluntary nature of CSR [33], CSR committees can assist in the compliance with these normative pressures. However, beyond normative pressures and governance codes, some institutions have also encouraged the suitability of having a CSR committee. For example, the International Institute for Sustainable Development (IISD) recommends developing an integrated CSR decision-making structure. To this end, the guide recommends "identifying people or committees at the top levels of the firm who will assume key CSR decision making responsibilities." [34] (p. 58). The report provides different options for board participation: "a sitting board member could be tasked with the broad responsibility for overseeing CSR activities; a new member who has specific CSR expertise could be appointed; CSR responsibilities could be added to the work of existing board committees; a new CSR board committee could be formed; or the entire board could be involved in CSR decisions." [34] (p. 58).

Spanish standard SGE 21, launched by Forética, is "the first European standard that since 2000 has allowed organizations to implement, audit and certify and ethical and socially responsible management system." [35]. This standard complies with trends in international codes of good governance and transparency and article 6.1.3. includes guidelines on the implementation of a CSR committee [36]. It states the advisory nature of the committee and its duties (review and interpretation of CSR policies and Codes of Conduct, the supervision of the degree of compliance with objectives and goals) as well as its composition and the human, material, and human resources secured to ensure alignment with the strategy and objectives of the organization. Additionally, the standard refers to practical issues such as the regularity of committee meetings and communication mechanisms with the highest bodies and stakeholders.

Despite the lack of institutionalization of the implementation of CSR committees, companies are incorporating them into their management. In the website CSR and the Law, [37] reviewed the responsibilities of the CSR committees from different firms (e.g., Phillips-Van Heusen Corporation, McDonald's, Tiffany \& Co, Hasbro, Heinz Company or Bank of New York). Among these responsibilities, Phillips-Van Heusen and Hasbro included making recommendations regarding proposals of corporate social responsibility issues, McDonald's corporation included reviewing trends with significant impacts of the company; Tiffany \& Co included recommending goals and practices of CSR to the Board of Directors; and BNY Mellon included providing oversight over operations and programs. [5] reviewed the terms of references of board CSR committees and stated that they tended to focus on reviewing CSR issues, identifying non-financial risks and monitoring risk management, establishing policies and standards, monitoring compliance with and performance against the companies CSR policies, reviewing company reporting on CSR, and overseeing philanthropic activity. Thus, the creation of a committee responds to "better board effectiveness, by delegating some tasks to fewer decision makers" [9] (p. 1926) and can be summarized as tasks for prospecting CSR actions, identifying trends, risk management, and accountability.

The CSR committee is beginning to gain in importance when implementing a CSR policy, as it "has overall responsibility for formulating, implementing and monitoring the CSR strategy within each group and its entities" [38]. Previous studies have proven the effect of CSR committees on being at the highest group of corporate social performance and higher CSR committee effectiveness [9], on the level of disclosure related to CSR [39-42], and on the level of alignment of sustainability reports with respect to the GRI guidelines [14]. This leads us to raise our first hypothesis, tested separately for the four countries and the four considered scores.

Hypothesis 1 (H1). Companies with CSR committees are more sustainable than companies without CSR committees. 
Exploring the effect of the presence of a committee responsible for CSR was raised by [33] with regard to the profitability of the firms. They found that the profitability of firms with a CSR committee on their corporate boards did not significantly differ from those without a CSR committee. The relationship between CSR committees and other types of performance was explored by [8] and [7]. The use of component ratings of corporate social performance by [8] allowed them to confirm that CSR committees were positively associated with community performance and human rights performance, and not for the overall corporate social performance (CSP). A similar result was obtained by [7], who demonstrated that CSR committees influenced the CSP strengths and CSP concerns, but not the CSP score. These results enhance the idea of using disaggregated indicators to analyze the impact of CSR committees. Consequently, knowing the different impacts will allow the corporate board to act accordingly, changing, for example, their composition. Considering this, we hypothesized that the presence of a CSR or sustainability committee positively affected the four ESG scores, following the line of $[7,25]$. The following hypotheses will be also tested for the four countries.

Hypothesis 2 (H2). CSR committees are positively associated with Social Scores.

Hypothesis 3 (H3). CSR committees are positively associated with Environmental Scores.

Hypothesis 4 (H4). CSR committees are positively associated with Corporate Governance Scores.

Hypothesis $\mathbf{5}$ (H5). CSR committees are positively associated with Economic Scores.

\section{Materials and Methods}

\subsection{Sample of European Companies}

The sample was composed of listed firms from Spain, France, Germany, and the UK for the period 2005-2015. Regarding World Bank data in 2018 [43], they were among the largest economies in Europe (Germany, the UK, and France are in the top three in terms of US\$ GDP). We selected Spanish listed companies instead of Italian listed companies for representativeness reasons, as the market capitalization of Spanish listed companies (in \% of GDP) is higher than the market capitalization of Italian listed companies [44]. In addition, listed companies in Spain represent all corporate structure systems (one-tier or two tier systems, depending on whether there are one or two separate boards of directors: supervisory board and management board). Information about CSR committees and certain pillars of ESG scores is not available for all of the companies in the considered period, so the final sample was composed by 197 firms (1693 observations) from Spain (33 companies out of 35 listed on Ibex35, 248 observations in total), France (39 companies out of 40 listed on CAC 40, 353 observations in total), Germany (29 companies out of 30 listed on DAX 30, 211 observations in total), and the UK (96 companies out of 100 listed on FTSE100, 881 observations in total). Note that not all companies provided information for the whole period (observations are also included in the brackets), so we had an unbalanced data panel. Models were considered independently for each country and the information was obtained from the Datastream database.

\subsection{Model and Variables}

We developed two types of analysis to respond to the objective and hypotheses of the study. First, we obtained the correlation matrix to analyze all pair correlations. There were no high pair-wise correlations, so did not indicate any collinearity problems. After analyzing the correlation, we divided the sample of the four considered countries into two groups: companies that had a CSR committee and companies that did not have a CSR committee. In order to test whether firms with a CSR committee were more sustainable, we performed a Levene's test for the equality of variances with the SPSS software. Second, in order to evaluate whether having a CSR committee had an impact on ESG and economic scores, we regressed the ESG scores (social scores in Equation (1), environmental scores in 
Equation (2), corporate governance scores in Equation (3), and economic scores in Equation (4)) on a dummy variable to indicate whether the firm had a CSR committee. To do this, we had an unbalanced panel of 197 firms (1693 observations) and we used the plm package of the R project for Statistical Computing [45]. Panel data techniques tend to be the best methodology to analyze companies' behavior over time, as it allows for the analysis of the same companies over consecutive years. This technique is the most recently used in similar studies $[8,14]$. We included firm $\left(\alpha_{i}\right)$ and year $\left(\delta_{t}\right)$ fixed-effects or random effects for each model, depending on the results of the Hausman test, testing whether the unique errors were correlated with the regressors [30]. The null hypothesis in the preferred model is random effects. We also controlled for the following firm-characteristics: independence of the board, non-executive members, size of the board, chairman CEO-Chairman separation, firm size, profitability, and indebtedness by following similar models such as those in $[7,8,46]$. The models were tested in each of the four considered countries: Spain, Germany, France, and the UK. Table 1 shows the measurements of the variables.

$$
\begin{aligned}
& S S_{i t}=\beta_{0}+\alpha_{i}+\delta_{t}+\beta_{1} C S R_{\text {COMit }}+\beta_{2} B_{I N D i t}+\beta_{3} B_{N E M i t}+\beta_{4} B_{\text {SIZEit }}+\beta_{5} C E O_{S E P i t}+ \\
& \beta_{6} S_{I Z E_{i t}}+\beta_{7} R O A_{i t}+\beta_{8} D E B T_{i t}+\varepsilon_{i t} \\
& E S_{i t}=\beta_{0}+\alpha_{i}+\delta_{t}+\beta_{1} C S R_{\text {COMit }}+\beta_{2} B_{\text {INDit }}+\beta_{3} B_{N E M i t}+\beta_{4} B_{\text {SIZEit }}+\beta_{5} C E O_{S E P i t}+ \\
& \beta_{6} S_{I Z E_{i t}}+\beta_{7} R O A_{i t}+\beta_{8} D E B T_{i t}+\varepsilon_{i t} \\
& C G S_{i t}=\beta_{0}+\alpha_{i}+\delta_{t}+\beta_{1} C S R_{\text {COMit }}+\beta_{2} B_{I N D i t}+\beta_{3} B_{N E M i t}+\beta_{4} B_{\text {SIZEit }}+\beta_{5} C E O_{\text {SEPit }}+ \\
& \beta_{6} S_{I Z E_{i t}}+\beta_{7} R O A_{i t}+\beta_{8} D E B T_{i t}+\varepsilon_{i t} \\
& E c S_{i t}=\beta_{0}+\alpha_{i}+\delta_{t}+\beta_{1} C S R_{\text {COMit }}+\beta_{2} B_{I N D i t}+\beta_{3} B_{N E M i t}+\beta_{4} B_{\text {SIZEit }}+\beta_{5} C E O_{S E P i t}+ \\
& \beta_{6} S I Z E_{i t}+\beta_{7} R O A_{i t}+\beta_{8} D E B T_{i t}+\varepsilon_{i t}
\end{aligned}
$$

\begin{tabular}{|c|c|}
\hline Variable & Measurement \\
\hline \multicolumn{2}{|r|}{ Dependent variable } \\
\hline \multicolumn{2}{|c|}{$\begin{array}{l}\text { Regressions equations differ on the dependent variable: } 1 \text { Social Score, } 2 \text { Environmental Score, } 3 \text { Corporate } \\
\text { Governance Score, and } 4 \text { Economic Score. All scores were obtained from the Asset } 4 \text { database. }\end{array}$} \\
\hline \multicolumn{2}{|r|}{ Independent variable } \\
\hline $\mathrm{CSR}_{\mathrm{COM}}$ & $\begin{array}{l}\text { Dummy variable (yes }=1 / \text { no }=0 \text { ) responding the question "Does the company have a CSR } \\
\text { committee or team?" (Variable CSR Sustainability Committee) }\end{array}$ \\
\hline \multicolumn{2}{|r|}{ Control variables } \\
\hline $\mathrm{B}_{\mathrm{IND}}$ & $\begin{array}{l}\text { Percentage of independent board members as reported by the company (variable } \\
\text { Independent Board Members) }\end{array}$ \\
\hline $\mathrm{B}_{\mathrm{NEM}}$ & Percentage of non-executive board members (variable Non-Executive Board Members) \\
\hline $\mathrm{B}_{\mathrm{SIZE}}$ & Total number of board members at the end of fiscal year (variable Board Size) \\
\hline $\mathrm{CEO}_{\mathrm{SEP}}$ & $\begin{array}{l}\text { Dummy variable (yes }=1 / \text { no }=0 \text { ) responding the question "Does the CEO simultaneously } \\
\text { chair the board?" (variable CEO-Chairman Separation Q1) }\end{array}$ \\
\hline SIZE & Number of employees \\
\hline ROA & EBIT/Total assets \\
\hline DEBT & Debt to equity ratio \\
\hline
\end{tabular}

Table 1. Measurement of variables. Source: authors.

Note: All the variables were obtained from the Asset4 database (Datastream).

\subsubsection{Dependent Variables}

We wanted to know whether having a CSR Committee influenced the ESG performance. In order to measure ESG performance, researchers have used information provided by KLD Research \& Analytics, ESG ratings, or Sustainalytics [47]. We used ESG scores provided by the Asset4 database by Thomson Reuters Datastream. This database provides comprehensive coverage, so these ESG scores are being 
used more and more by diverse authors $[24,46,48]$ and "are designed to transparently and objectively measure a company's relative ESG performance" [49]. In order to capture the influencing impact of CSR committees on ESG scores, we used the next year's ESG scores following the line of [14].

- Social score (SS). "It measures a company's capacity to generate trust and loyalty with is workforce, customers and society, through its use of best management practices" [49].

- Environmental Score (ES). "It measures a company's impact on living and non-living natural systems, including the air, land and water, as well as complete ecosystems" [49].

- Corporate Governance Score (CGS). "It measures a company's systems and processes, which ensure that its board members and executives act in the best interests of its long term shareholders" [49].

- Economic Score (EcS). "It measures a company's capacity to generate sustainable growth and a high return on investment through the efficient use of all its resources" [49].

\subsubsection{Independent Variables}

In this study, the independent variable was the existence of a CSR Committee. This is a dummy variable that equals 1 if the company has a CSR committee and 0 otherwise. Figure 1 and Table 2 show the evolution of listed companies with a CSR committee in the sample of the four considered countries. Across the whole sample, listed companies evolved from 31\% of them having a CSR committee in 2005 to $90 \%$ of them having a CSR committee in 2014.

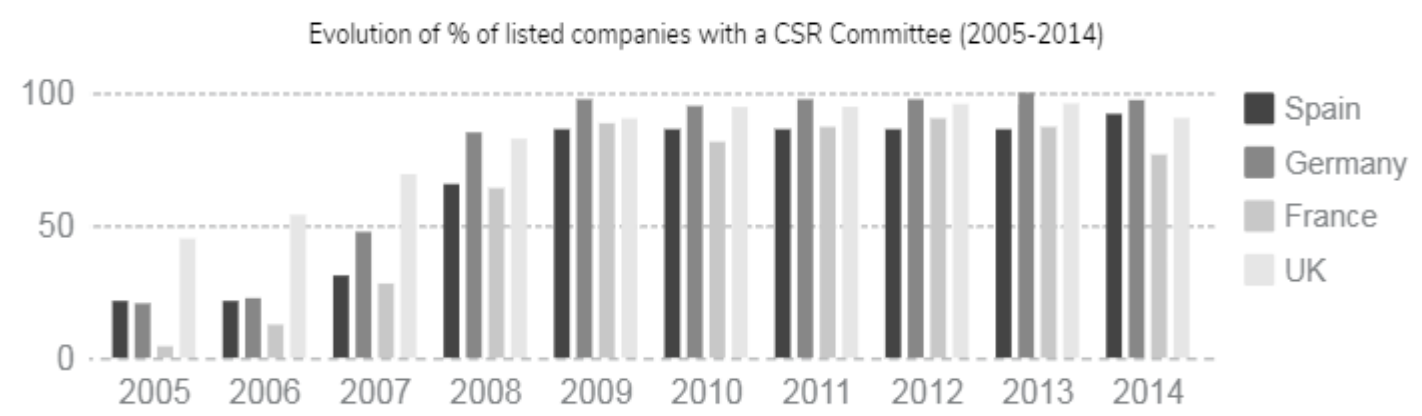

Figure 1. Percentage of listed companies with a CSR committee for the period 2005-2014. Source: authors with information from Asset4.

Table 2. \% of listed companies with a CSR committee. Period 2005-2014. Source: Asset4.

\begin{tabular}{ccccccccccc}
\hline & $\mathbf{2 0 0 5}$ & $\mathbf{2 0 0 6}$ & $\mathbf{2 0 0 7}$ & $\mathbf{2 0 0 8}$ & $\mathbf{2 0 0 9}$ & $\mathbf{2 0 1 0}$ & $\mathbf{2 0 1 1}$ & $\mathbf{2 0 1 2}$ & $\mathbf{2 0 1 3}$ & $\mathbf{2 0 1 4}$ \\
\hline Spain & 21.43 & 21.43 & 31.03 & 65.52 & 86.21 & 86.21 & 86.21 & 86.21 & 86.21 & 92 \\
Germany & 20.51 & 22.50 & 47.50 & 85 & 97.50 & 95 & 97.50 & 97.50 & 100 & 97.22 \\
France & 4.35 & 12.50 & 28.00 & 64 & 88.46 & 81.48 & 87.10 & 90.32 & 87.10 & 76.67 \\
UK & 44.94 & 53.93 & 69.23 & 82.61 & 90.22 & 94.62 & 94.68 & 95.83 & 95.88 & 90.43 \\
\hline
\end{tabular}

\subsubsection{Control Variables}

The drivers of ESG performance are diverse, so we used control variables similar to those used in other studies [50]: board independence, board size, CEO-Chair separation, firm size, return on assets (ROA), and debt ratio. Independence and size of the board respond to the fact that more diverse and experienced board members guarantee a sense of alignment with the objectives of other groups of interest [51] and are "more likely to resolve conflicts by making a balance between a firm's financial and non-financial goals" [52] (p. 348). Role duality is controversial, as it can be understood as the reduction of the effectiveness of the monitoring role of the board or, on the other, hand, increasing board independency [52,53]. We included firm size, ROA, and debt-to-equity ratio as firm-specific characteristics following $[24,51,54]$. Larger companies in size and profitability usually have better CSR 
performance due to the higher availability of resources. On the other hand, more indebted companies have a lower availability of resources, so they have a lower chance of investing in CSR.

\section{Results}

Table 3 shows the descriptive statistics of the variables used in the regression model. ESG and economic scores ranged from 0 to 100. The highest average score was the social score in Germany and Spain, followed by the environmental score, the economic score, and the corporate governance score. In France, the highest average score was the environmental score, followed by the social score, the economic score, and the corporate governance scores. In the UK, the highest average score was the corporate governance score, followed by the social score, the environmental score, and the economic score.

Table 3. Descriptive statistics. Source: authors.

\begin{tabular}{|c|c|c|c|c|c|c|c|c|c|c|c|c|}
\hline \multirow{2}{*}{ Variable } & \multicolumn{3}{|c|}{ Germany } & \multicolumn{3}{|c|}{ France } & \multicolumn{3}{|c|}{ Spain } & \multicolumn{3}{|c|}{ The UK } \\
\hline & Min. & Max. & Mean & Min. & Max. & Mean & Min. & Max. & Mean & Min. & Max. & Mean \\
\hline Social Score & 20.7 & 98.6 & 86.2 & 39.8 & 98.6 & 89.3 & 5.1 & 98.6 & 87.8 & 11.7 & 98.7 & 79.3 \\
\hline $\begin{array}{l}\text { Environmental } \\
\text { Score }\end{array}$ & 9.6 & 96.9 & 85.8 & 17.0 & 97.0 & 89.5 & 12.1 & 96.9 & 82.9 & 12.5 & 96.9 & 76.7 \\
\hline CG Score & 4.5 & 93.3 & 47.2 & 14.8 & 97.4 & 70.4 & 4.9 & 94.6 & 63.7 & 17.7 & 97.6 & 81.9 \\
\hline Economic Score & 8.0 & 98.7 & 79.2 & 1.4 & 99.1 & 79.4 & 11.0 & 97.9 & 76.7 & 2.4 & 99.1 & 72.1 \\
\hline $\mathrm{CSR}_{\mathrm{COM}}$ & 0.0 & 1.0 & 0.7 & .0 & 1.0 & 0.8 & 0.0 & 1.0 & 0.6 & 0.0 & 1.0 & 0.8 \\
\hline $\mathrm{B}_{\mathrm{IND}}$ & 0.0 & 100.0 & 15.0 & .0 & 100.0 & 57.5 & 0.0 & 100.0 & 46.9 & 0.0 & 100.0 & 57.9 \\
\hline $\mathrm{B}_{\mathrm{NEM}}$ & 65.0 & 100.0 & 99.7 & 38.5 & 100.0 & 89.3 & 55.6 & 100.0 & 81.4 & 20.0 & 100.0 & 69.5 \\
\hline $\mathrm{B}_{\text {SIZE }}$ & 6.0 & 23.0 & 17.0 & 6.0 & 24.0 & 14.3 & 8.0 & 24.0 & 14.2 & 4.0 & 21.0 & 11.1 \\
\hline $\mathrm{CEO}_{\mathrm{SEP}}$ & 0.0 & 1.0 & 0.2 & 0.0 & 1.0 & 0.6 & 0.0 & 1.0 & 0.5 & 0.0 & 1.0 & 0.1 \\
\hline $\begin{array}{l}\text { SIZE (th } \\
\text { employees) }\end{array}$ & 2.9 & 563 & 124.8 & 0.9 & 495.2 & 117 & 0.02 & 319.5 & 50.9 & 0.001 & 537.7 & 51.2 \\
\hline ROA & -10.4 & 29.0 & 6.7 & -13.1 & 24.7 & 6.4 & -15.2 & 51.1 & 7.0 & -38.6 & 117.4 & 10.2 \\
\hline DEBT & 0.0 & 32.4 & 1.8 & 0.0 & 4.6 & 0.9 & -15.4 & 14.1 & 2.1 & -225.8 & 266.8 & 1.1 \\
\hline
\end{tabular}

Although the evolution of ESG scores was positive in the four considered scores, we spotted higher differences in the corporate governance score (Figure 2 and Table 4). Note that the dependent variable lagged one year, so the period of ESG and economic scores was 2006-2015. German companies evolved from a score of 40.81 to 53.27, but there was a big difference with the English companies, whose corporate governance scores have traditionally always been higher.
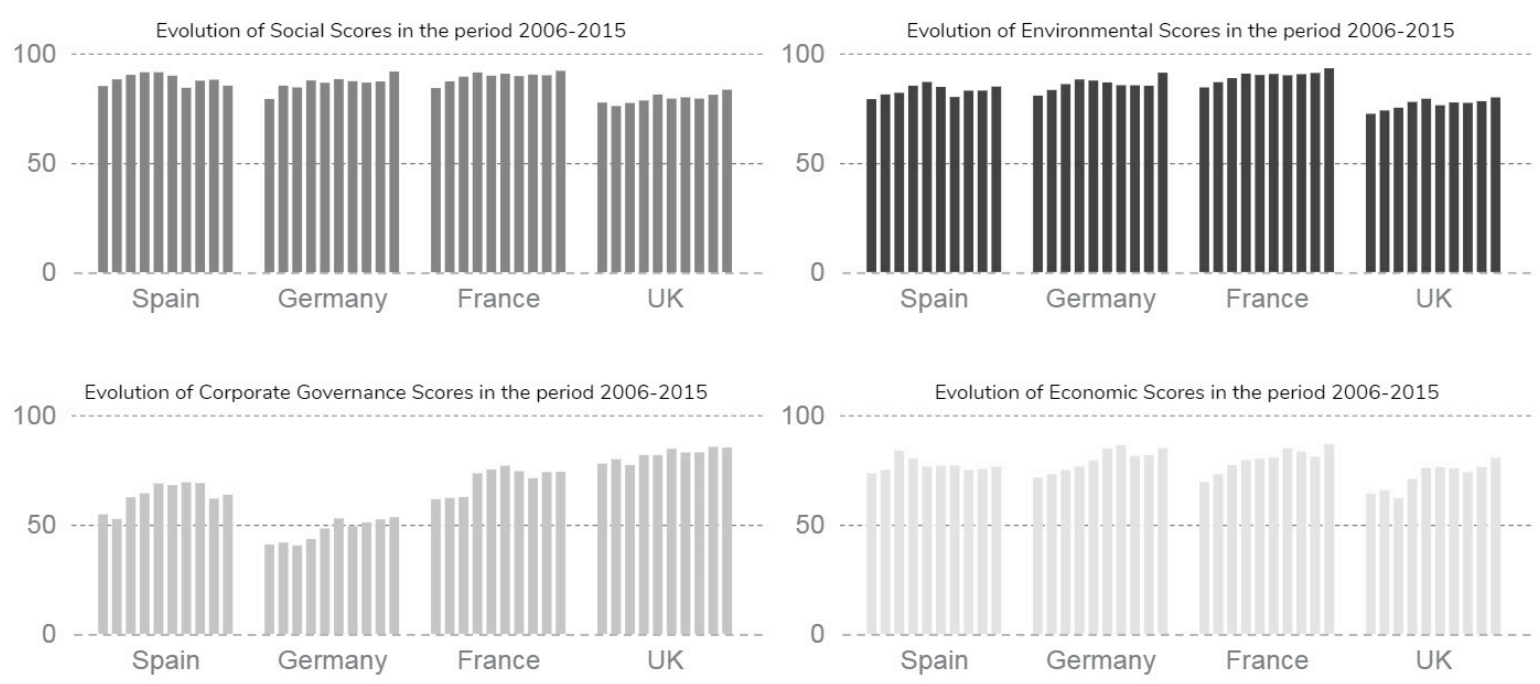

Figure 2. Average of social, environmental, corporate governance, and economic scores by country for the period 2006-2015. Source: Authors with data from Asset4. 
Table 4. Evolution of social, environmental, corporate governance, and economic scores by country for the period 2006-2015. Source: Asset4.

\begin{tabular}{cccccccccccc}
\hline & & $\mathbf{2 0 0 6}$ & $\mathbf{2 0 0 7}$ & $\mathbf{2 0 0 8}$ & $\mathbf{2 0 0 9}$ & $\mathbf{2 0 1 0}$ & $\mathbf{2 0 1 1}$ & $\mathbf{2 0 1 2}$ & $\mathbf{2 0 1 3}$ & $\mathbf{2 0 1 4}$ & $\mathbf{2 0 1 5}$ \\
\hline & Spain & 84.95 & 87.99 & 90.03 & 91.21 & 91.24 & 89.65 & 84.12 & 87.41 & 87.82 & 85.1 \\
Social Score & Germany & 79.03 & 85.19 & 84.31 & 87.5 & 86.43 & 88.1 & 87.14 & 86.52 & 87.04 & 91.55 \\
& France & 84.04 & 87.07 & 89.21 & 91.13 & 89.68 & 90.55 & 89.48 & 90.15 & 89.83 & 91.86 \\
& UK & 77.39 & 75.82 & 77.22 & 78.34 & 81.06 & 79.2 & 79.78 & 79.2 & 80.96 & 83.26 \\
& Spain & 79 & 81.13 & 81.87 & 85.12 & 86.82 & 84.57 & 79.98 & 82.87 & 82.9 & 84.71 \\
Environmental & Germany & 80.59 & 83.15 & 85.83 & 87.96 & 87.46 & 86.62 & 85.33 & 85.28 & 85.11 & 91.06 \\
Score & France & 84.32 & 86.73 & 88.61 & 90.64 & 90.02 & 90.48 & 89.87 & 90.39 & 90.93 & 93.08 \\
& UK & 72.28 & 73.81 & 75.08 & 77.71 & 79.18 & 76.18 & 77.47 & 77.29 & 78.06 & 79.78 \\
& Spain & 54.53 & 52.4 & 62.3 & 64.12 & 68.62 & 67.88 & 69.14 & 68.81 & 61.72 & 63.51 \\
Corporate & Spain & 40.81 & 41.67 & 40.32 & 43.28 & 48.05 & 52.72 & 49.12 & 50.87 & 52.21 & 53.27 \\
Governance & Germany & 61.39 & 62.01 & 62.45 & 73.27 & 75.05 & 76.75 & 74.18 & 71.02 & 73.8 & 73.94 \\
Score & France & 77.72 & 79.7 & 77.04 & 81.61 & 81.61 & 84.44 & 82.77 & 82.82 & 85.34 & 85.04 \\
& UK & 73.21 & 74.89 & 83.63 & 80.02 & 76.37 & 76.86 & 76.77 & 74.7 & 75.23 & 76.3 \\
& Spain & 71.33 & 72.81 & 74.86 & 76.39 & 79.11 & 84.59 & 86.11 & 81.15 & 81.58 & 84.76 \\
Economic Score & Germany & 69.34 & 72.87 & 77.07 & 79.32 & 79.88 & 80.45 & 84.6 & 83.14 & 80.78 & 86.57 \\
& France & 64 & 65.5 & 61.89 & 70.72 & 75.74 & 76.13 & 75.55 & 73.7 & 76.15 & 80.39 \\
& UK & 84.95 & 87.99 & 90.03 & 91.21 & 91.24 & 89.65 & 84.12 & 87.41 & 87.82 & 85.1 \\
\hline
\end{tabular}

Table 5 presents the Pearson correlation matrix for the variables in the model for the four considered countries. The variable CSR committee (CSR $\mathrm{COM}$ ) correlated positively and significantly with all ESG and economic scores (SS, ES, CGS, and EcS) in the four countries, except for the social scores in Spain. Board independence only correlated significantly and positively with the corporate governance score. However, non-executive members, board size, and CEO separation correlated positively and significantly with the social, environmental, and economic scores, but negatively with the corporate governance score.

We conducted an independent samples t-test to test whether there was statistical evidence that the means of two independent groups (those with and without a CSR committee) were significantly different. We performed this test because our dependent variables (ESG scores) were metric variables that were normally distributed (Kolmogorov-Smirnov and Shapiro-Wilk p-values lower than 0.05 in all scores). In all cases, with the exception of the corporate governance scores in Germany (where Levene's test was not rejected), we considered that equal variances were not assumed. Table 6 shows the score averages by country in the groups with and without a CSR committee and the t-test for the equality of means. In the four countries, the average of ESG scores in companies with a CSR committee was higher than those in companies without a CSR committee. In all cases, there was a significant difference in the average scores between companies with and without CSR committees.

Results of the regression models are shown in Tables 5-8. Depending on the results of the Hausman test, we considered the random effects in the social, environmental, and corporate governance score models in Spain and France (fixed effects in Germany and the UK) and random effects in the economic score model in Germany (fixed effects in Spain, France, and the UK). We also included the modified BNF statistic (the generalized Durbin-Watson statistic for panels) for the unbalanced panels, the Baltagi-Wu's LBI test, performed with the pbnftest in R. Most of the values were considered normal, with values around 2 [55].

Regarding social performance, we found that CSR committees significantly and positively affected social scores in Spain, Germany, France, and the UK, so H2 was confirmed. In Spain, the social scores were also influenced by the independence (also in the UK) and the size of the board (see Table 7). However, the relationship with non-executive members was negative. In Germany, higher social scores were obtained by larger companies. 
Table 5. Correlation matrix.

\begin{tabular}{|c|c|c|c|c|c|c|c|c|c|c|c|c|c|c|c|c|}
\hline \multirow[b]{2}{*}{ Var } & \multicolumn{8}{|c|}{ Spain } & \multicolumn{8}{|c|}{ Germany } \\
\hline & $\mathrm{CSR}_{\mathrm{COM}}$ & $\mathrm{B}_{\mathrm{IND}}$ & $\mathrm{B}_{\mathrm{NEM}}$ & $\mathrm{B}_{\text {SIZE }}$ & $\mathrm{CEO}_{\mathrm{SEP}}$ & SIZE & ROA & DEBT & $\mathrm{CSR}_{\mathrm{COM}}$ & $\mathrm{B}_{\mathrm{IND}}$ & $\mathrm{B}_{\mathrm{NEM}}$ & $\mathrm{B}_{\mathrm{SIZE}}$ & $\mathrm{CEO}_{\mathrm{SEP}}$ & SIZE & ROA & DEBT \\
\hline $\mathrm{SC}$ & 0.054 & 0.055 & -0.052 & $0.304^{* *}$ & $0.116^{*}$ & $0.259 * *$ & $\underset{*}{-0.115}$ & $0.132^{* *}$ & $\underset{* * *}{0.355}$ & $-\underset{* *}{0.140}$ & -0.021 & $\underset{* * *}{0.346}$ & 0.042 & $\underset{* * *}{0.335}$ & $-\underset{* * *}{0.165}$ & -0.002 \\
\hline ES & $\underset{* * *}{0.266}$ & 0.080 & -0.090 & $0.124^{* *}$ & $0.149^{* *}$ & $\underset{* * *}{0.349}$ & -0.076 & 0.093 & $\underset{* * *}{0.306}$ & $-\underset{* *}{0.152}$ & -0.044 & $\begin{array}{c}0.409 \\
* * *\end{array}$ & -0.026 & $\underset{* * *}{0.374}$ & $\underset{* * *}{0.234}$ & -0.029 \\
\hline CGS & $\underset{* * *}{0.322}$ & $0.34^{* * *}$ & -0.053 & -0.051 & -0.007 & $\underset{* * *}{0.276}$ & $-\underset{* * *}{0.162}$ & $\underset{* * *}{0.196}$ & $\underset{* * *}{0.215}$ & $\underset{* * *}{0.273}$ & -0.033 & 0.050 & 0.032 & $\underset{* * *}{0.346}$ & -0.083 & 0.091 \\
\hline $\mathrm{E}_{\mathrm{C}} \mathrm{S}$ & $0.145^{* *}$ & $0.046^{* *}$ & -0.123 & 0.059 & -0.049 & $\underset{* * *}{0.272}$ & -0.004 & $\underset{* * *}{0.238}$ & $\underset{* * *}{0.324}$ & 0.075 & 0.037 & 0.090 & -0.014 & $\underset{* * *}{0.341}$ & -0.023 & -0.061 \\
\hline $\mathrm{CSR}_{\mathrm{COM}}$ & 1 & $0.126^{* *}$ & 0.050 & 0.066 & $0.121^{* *}$ & $\underset{* * *}{0.169}$ & $\begin{array}{c}-0.114 \\
*\end{array}$ & -0.059 & 1 & $-\underset{* * *}{0.220}$ & $0.115^{*}$ & $\underset{* * *}{0.241}$ & -0.007 & $\underset{* * *}{0.272}$ & $-\underset{* *}{-0.118}$ & 0.008 \\
\hline $\mathrm{B}_{\mathrm{IND}}$ & & 1 & $\underset{* * *}{-0.189}$ & $\underset{* * *}{-0.305}$ & 0.013 & $\begin{array}{c}-0.153 \\
* *\end{array}$ & -0.049 & $0.103^{*}$ & & 1 & -0.044 & $\underset{* *}{-0.154}$ & -0.030 & 0.003 & $0.114^{*}$ & -0.105 \\
\hline $\mathrm{B}_{\mathrm{NEM}}$ & & & 1 & 0.082 & $\underset{* * *}{0.166}$ & $\underset{* *}{-0.135}$ & 0.093 & $\underset{* *}{-0.139}$ & & & 1 & $-\underset{* * *}{-0.051}$ & $\underset{* * *}{-0.055}$ & -0.016 & 0.037 & 0.025 \\
\hline $\mathrm{B}_{\text {SIZE }}$ & & & & 1 & $\underset{* * *}{0.183}$ & $\underset{* * *}{0.383}$ & $\underset{* * *}{-0.220}$ & 0.029 & & & & 1 & $\underset{* * *}{0.282}$ & $\underset{* * *}{0.481}$ & $\underset{* * *}{-0.373}$ & $\underset{* * *}{0.154}$ \\
\hline $\mathrm{CEO}_{\mathrm{SEP}}$ & & & & & 1 & 0.045 & -0.068 & 0.039 & & & & & 1 & $\underset{* * *}{0.215}$ & $\underset{* * *}{-0.206}$ & 0.053 \\
\hline SIZE & & & & & & 1 & $\underset{* * *}{-0.461}$ & $\underset{* * *}{0.322}$ & & & & & & 1 & $\underset{* * *}{-0.600}$ & $\underset{* * *}{0.429}$ \\
\hline \multirow[t]{2}{*}{ ROA } & & & & & & & 1 & $\underset{* * *}{-0.266}$ & & & & & & & 1 & -0.285 \\
\hline & \multicolumn{8}{|c|}{ France } & \multicolumn{8}{|c|}{ UK } \\
\hline Var & $\mathrm{CSR}_{\mathrm{COM}}$ & $\mathrm{B}_{\mathrm{IND}}$ & $\mathrm{B}_{\mathrm{NEM}}$ & $\mathrm{B}_{\text {SIZE }}$ & $\mathrm{CEO}_{\mathrm{SEP}}$ & SIZE & ROA & DEBT & $\mathrm{CSR}_{\mathrm{COM}}$ & $\mathrm{B}_{\mathrm{IND}}$ & $\mathrm{B}_{\mathrm{NEM}}$ & $\mathrm{B}_{\text {SIZE }}$ & $\mathrm{CEO}_{\mathrm{SEP}}$ & SIZE & $\mathrm{ROA}$ & DEBT \\
\hline SC & $\underset{* * *}{0.180}$ & -0.008 & $\begin{array}{c}-0.096 \\
*\end{array}$ & $0.086^{*}$ & $\underset{* * *}{0.142}$ & $\underset{* * *}{0.274}$ & -0.060 & -0.024 & $\underset{* * *}{0.309}$ & -0.008 & $\underset{* *}{-0.096}$ & $0.086^{*}$ & $\underset{* *}{-0.083}$ & $\underset{* * *}{0.274}$ & -0.060 & -0.023 \\
\hline ES & $\underset{* * *}{0.125}$ & $\underset{* *}{-0.120}$ & $-\underset{* * *}{-0.169}$ & 0.074 & $\underset{* * *}{0.159}$ & $\underset{* * *}{0.252}$ & -0.009 & -0.059 & $\underset{* * *}{0.327}$ & $-\underset{* *}{0.120}$ & $-\underset{* * *}{-0.169}$ & 0.074 & -0.082 & $\underset{* * *}{0.252}$ & -0.009 & -0.059 \\
\hline CGS & $\underset{* * *}{0.288}$ & $\underset{* * *}{0.328}$ & 0.095 * & $\underset{* * *}{-0.167}$ & 0.009 & $\underset{* * *}{0.275}$ & -0.049 & $\underset{* *}{-0.118}$ & $\begin{array}{c}0.237 \\
* * *\end{array}$ & $\underset{* * *}{0.328}$ & $0.095^{* *}$ & $-\underset{* * *}{-0.167}$ & $\begin{array}{c}-0.064 \\
*\end{array}$ & $\underset{* * *}{0.275}$ & -0.049 & $\underset{* *}{-0.118}$ \\
\hline $\mathrm{E}_{\mathrm{C}} \mathrm{S}$ & $\underset{* * *}{0.157}$ & 0.083 & -0.074 & 0.052 & $\underset{* * *}{0.236}$ & 0.026 & $\underset{* * *}{0.166}$ & $\underset{* * *}{-0.241}$ & $\underset{* * *}{0.274}$ & 0.083 & -0.074 & 0.052 & $\underset{* * *}{-0.148}$ & 0.026 & $\underset{* * *}{0.166}$ & $\underset{* * *}{-0.241}$ \\
\hline
\end{tabular}


Table 5. Cont.

\begin{tabular}{|c|c|c|c|c|c|c|c|c|c|c|c|c|c|c|c|c|}
\hline \multirow[b]{2}{*}{$\mathrm{CSR}_{\mathrm{COM}}$} & \multicolumn{8}{|c|}{ Spain } & \multicolumn{8}{|c|}{ Germany } \\
\hline & 1 & $\begin{array}{c}-0.086 \\
*\end{array}$ & -0.108 & $\underset{* * *}{0.193}$ & 0.091 * & $\underset{* * *}{0.181}$ & $\underset{* * *}{-0.165}$ & $\underset{* * *}{0.160}$ & 1 & $\begin{array}{c}-0.086 \\
*\end{array}$ & -0.018 & $\underset{* * *}{0.193}$ & 0.091 * & $\underset{* * *}{0.181}$ & $\underset{* * *}{-0.165}$ & $\underset{* * *}{0.160}$ \\
\hline $\mathrm{B}_{\mathrm{IND}}$ & & 1 & $\underset{* * *}{0.406}$ & $-\underset{* * *}{0.422}$ & -0.031 & $\underset{* *}{-0.107}$ & $\underset{* * *}{0.145}$ & $-\underset{* * *}{-0.167}$ & & 1 & $\underset{* * *}{0.406}$ & $-\underset{* * *}{0.422}$ & -0.031 & $\underset{* *}{-0.107}$ & $0.145^{* * *}$ & $\underset{* * *}{-0.167}$ \\
\hline $\mathrm{B}_{\mathrm{NEM}}$ & & & 1 & $\underset{* * *}{-0.296}$ & $\underset{* * *}{-0.205}$ & -0.084 & -0.010 & 0.074 & & & 1 & $\underset{* * *}{-0.296}$ & $\underset{* * *}{-0.205}$ & -0.084 & -0.010 & 0.074 \\
\hline $\mathrm{B}_{\mathrm{SIZE}}$ & & & & 1 & $\underset{* * *}{0.147}$ & $\underset{* * *}{0.361}$ & $\underset{* *}{-0.131}$ & -0.010 & & & & 1 & $\underset{* * *}{0.147}$ & $\underset{* * *}{0.361}$ & $\underset{* *}{-0.131}$ & -0.010 \\
\hline $\mathrm{CEO}_{\mathrm{SEP}}$ & & & & & 1 & 0.058 & $\underset{* * *}{0.164}$ & $\underset{* * *}{-0.201}$ & & & & & 1 & 0.058 & $\underset{* * *}{0.164}$ & $\underset{* * *}{-0.201}$ \\
\hline SIZE & & & & & & 1 & $\underset{* * *}{-0.345}$ & 0.063 & & & & & & 1 & $\underset{* * *}{-0.345}$ & 0.063 \\
\hline $\mathrm{ROA}$ & & & & & & & 1 & $\underset{* * *}{-0.271}$ & & & & & & & 1 & $\underset{* * *}{-0.271}$ \\
\hline
\end{tabular}

Note: Spearman's rho has been considered for dichotomous variables (CSRCOM and CEO_SEP) ${ }^{*}$ Correlation is significant at the 0.1 level (2-tailed), ${ }^{* *}$ Correlation is significant at the 0.05 level (2-tailed), ${ }^{* * *}$ Correlation is significant at the 0.01 level (2-tailed). Source: Authors. 
Table 6. Average ESG scores in groups without and with a CSR committee and significance of the t-test for the equality of means. Source: Authors.

\begin{tabular}{|c|c|c|c|c|c|}
\hline ESG Score & & Germany & France & Spain & UK \\
\hline \multirow[t]{3}{*}{$\begin{array}{l}\text { Social Score } \\
\text { average }\end{array}$} & $\begin{array}{c}\text { Listed companies } \\
\text { without a CSR } \\
\text { committee }\end{array}$ & 77.5 & 84.8 & 83.7 & 62.8 \\
\hline & $\begin{array}{c}\text { Listed companies } \\
\text { with a CSR } \\
\text { committee }\end{array}$ & 90.7 & 90.7 & 90.1 & 83.0 \\
\hline & $\begin{array}{c}t \text {-test for Equality } \\
\text { of Means }\end{array}$ & $\begin{array}{c}\mathrm{t}_{108.994}=6.425, \\
p<0.001\end{array}$ & $\begin{array}{c}\mathrm{t}_{109.576}=4.140 \\
p<0.001\end{array}$ & $\begin{array}{c}\mathrm{t}_{130.707}=2.875 \\
p<0.005\end{array}$ & $\begin{array}{c}\mathrm{t}_{194.740}=10.240, \\
p<0.001\end{array}$ \\
\hline \multirow[t]{3}{*}{$\begin{array}{l}\text { Environmental } \\
\text { Score average }\end{array}$} & $\begin{array}{c}\text { Listed companies } \\
\text { without a CSR } \\
\text { committee }\end{array}$ & 75.5 & 85.0 & 76.9 & 58.1 \\
\hline & $\begin{array}{c}\text { Listed companies } \\
\text { with a CSR } \\
\text { committee }\end{array}$ & 91.1 & 90.9 & 86.2 & 80.9 \\
\hline & $\begin{array}{l}t \text {-test for equality } \\
\text { of means }\end{array}$ & $\begin{array}{c}\mathrm{t}_{100.293}=5.579, \\
p<0.001\end{array}$ & $\begin{array}{c}\mathrm{t}_{103.288}=3.522 \\
p<0.001\end{array}$ & $\begin{array}{c}\mathrm{t}_{143.144}=4.391 \\
p<0.001\end{array}$ & $\begin{array}{c}\mathrm{t}_{197.897}=10.704 \\
p<0.001\end{array}$ \\
\hline \multirow{3}{*}{$\begin{array}{c}\text { Corporate } \\
\text { Governance Score } \\
\text { average }\end{array}$} & $\begin{array}{c}\text { Listed companies } \\
\text { without a CSR } \\
\text { committee }\end{array}$ & 40.6 & 60.3 & 54.2 & 74.5 \\
\hline & $\begin{array}{c}\text { Listed companies } \\
\text { with a CSR } \\
\text { committee }\end{array}$ & 50.6 & 73.6 & 68.8 & 83.5 \\
\hline & $\begin{array}{l}t \text {-test for equality } \\
\text { of means }\end{array}$ & $\begin{array}{c}\mathrm{t}_{282}=3.936 \\
p<0.001\end{array}$ & $\begin{array}{c}\mathrm{t}_{103.288}=3.522 \\
p<0.001\end{array}$ & $\begin{array}{c}\mathrm{t}_{163.872}=5.587 \\
p<0.001\end{array}$ & $\begin{array}{c}\mathrm{t}_{200.386}=7.139 \\
p<0.001\end{array}$ \\
\hline \multirow[t]{3}{*}{$\begin{array}{l}\text { Economic Score } \\
\text { average }\end{array}$} & $\begin{array}{l}\text { Listed companies } \\
\text { without a CSR } \\
\text { committee }\end{array}$ & 69.0 & 70.7 & 72.5 & 57.1 \\
\hline & $\begin{array}{c}\text { Listed companies } \\
\text { with a CSR } \\
\text { committee }\end{array}$ & 84.5 & 82.1 & 79.1 & 75.5 \\
\hline & $\begin{array}{l}t \text {-test for equality } \\
\text { of means }\end{array}$ & $\begin{array}{c}\mathrm{t}_{133.801}=5.833, \\
p<0.001\end{array}$ & $\begin{array}{c}\mathrm{t}_{103.288}=3.522 \\
p<0.001\end{array}$ & $\begin{array}{c}\mathrm{t}_{150.332}=2.204 \\
p<0.05\end{array}$ & $\begin{array}{c}\mathrm{t}_{219.498}=8.527 \\
p<0.001\end{array}$ \\
\hline
\end{tabular}

Regarding environmental performance, CSR committees significantly and positively affected environmental scores in Spain, Germany, France, and the UK, so H3 was confirmed (see Table 8). In Spain, the environmental scores were affected by independence (also in the UK) and size of the board. As in the social scores, they were also affected by non-executive members, but negatively. More profitable companies obtained higher environmental scores.

As for corporate governance performance, CSR committees significantly and positively affect corporate governance scores in Spain, Germany, France, and the UK, so H4 was confirmed (see Table 9). In Spain, corporate governance scores are affected by the size of the board (also in the UK) and the size of the company, as in Germany. In this case, the independence of the board was affected in France and in the UK. The UK is the only country where the separation of the CEO-Chairman negatively affected the achievement of corporate governance scores.

Results of the regression model on the economic score by country are shown in Table 8 . In this case, CSR committees significantly and positively affected the economic scores in Germany, France, and the UK, but not in Spain, so H5 was partially confirmed (see Table 10). This is consistent with previous results in the relationship between CSR committees and economic or financial performance [56]. In Spain, the economic scores were affected by independence and the size of the board and profitability of the company. Size of the company affected the economic scores positively in Germany and negatively in France. The UK, again, was the country where the separation of CEO-Chairman negatively affected the achievement of economic scores. 
Table 7. Results of the regression model by country with the social score as dependent variable. Source: Authors.

\begin{tabular}{|c|c|c|c|c|c|}
\hline \multicolumn{3}{|c|}{ Dependent Variable: Social Score-Spain } & \multicolumn{3}{|c|}{ Dependent Variable: Social Score-Germany } \\
\hline Variable & $\begin{array}{c}\text { Standardized } \\
\text { Coefficients }(\beta)\end{array}$ & $t$ & Variable & $\begin{array}{c}\text { Standardized } \\
\text { Coefficients }(\beta)\end{array}$ & $t$ \\
\hline $\mathrm{CSR}_{\mathrm{COM}}$ & 3.205 & $2.508^{* *}$ & $\mathrm{CSR}_{\mathrm{COM}}$ & 5.590 & $2.805^{* * *}$ \\
\hline $\mathrm{B}_{\mathrm{IND}}$ & 0.135 & $2.789 * * *$ & $\mathrm{~B}_{\mathrm{IND}}$ & -0.041 & -1.272 \\
\hline $\mathrm{B}_{\mathrm{NEM}}$ & -0.221 & $-2.475 * *$ & $\mathrm{~B}_{\mathrm{NEM}}$ & -0.021 & -0.084 \\
\hline $\mathrm{B}_{\mathrm{SIZE}}$ & 0.632 & $1.933 *$ & $\mathrm{~B}_{\mathrm{SIZE}}$ & 0.728 & 1.482 \\
\hline $\mathrm{CEO}_{\mathrm{SEP}}$ & -0.132 & -0.817 & $\mathrm{CEO}_{\mathrm{SEP}}$ & 1.042 & 0355 \\
\hline SIZE & 0.000 & 0.549 & SIZE & 0.000 & 1.970 * \\
\hline ROA & -0.004 & -0.046 & ROA & -0.358 & -1.51 \\
\hline DEBT & -0.012 & -0.038 & DEBT & 0.165 & 0.403 \\
\hline$R^{2}$ & \multicolumn{2}{|l|}{0.035} & $R^{2}$ & \multicolumn{2}{|c|}{0.136} \\
\hline Chi-Square & \multicolumn{2}{|c|}{ Not significant } & F statistic & \multicolumn{2}{|c|}{$3.4487 * * *$} \\
\hline Firm-effect & \multicolumn{2}{|c|}{ Included } & Firm-effect & \multicolumn{2}{|c|}{ Included } \\
\hline Year-effect & \multicolumn{2}{|c|}{ Included } & Year-effect & \multicolumn{2}{|c|}{ Included } \\
\hline Hausman Test & \multicolumn{2}{|c|}{11.205} & Hausman Test & \multicolumn{2}{|c|}{$65.589 * * *$} \\
\hline Type of panel data & \multicolumn{2}{|c|}{ Random } & Type of panel data & \multicolumn{2}{|c|}{ Fixed } \\
\hline LBI test & \multicolumn{2}{|l|}{1.60} & LBI test & \multicolumn{2}{|c|}{2.15} \\
\hline \multicolumn{3}{|c|}{ Dependent Variable: Social Score-France } & \multicolumn{3}{|c|}{ Dependent Variable: Social Score-UK } \\
\hline Variable & $\begin{array}{c}\text { Standardized } \\
\text { Coefficients }(\beta)\end{array}$ & $t$ & Variable & $\begin{array}{c}\text { Standardized } \\
\text { Coefficients }(\beta)\end{array}$ & $t$ \\
\hline $\mathrm{CSR}_{\mathrm{COM}}$ & 3.882 & $4.077^{* * *}$ & $\mathrm{CSR}_{\mathrm{COM}}$ & 6.001 & $5.961^{* * *}$ \\
\hline $\mathrm{B}_{\mathrm{IND}}$ & 0.006 & 0.222 & $\mathrm{~B}_{\mathrm{IND}}$ & 0.065 & $1.839 *$ \\
\hline $\mathrm{B}_{\mathrm{NEM}}$ & -0.040 & -0.831 & $\mathrm{~B}_{\mathrm{NEM}}$ & 0.028 & 0.525 \\
\hline $\mathrm{B}_{\mathrm{SIZE}}$ & 0.111 & 0.599 & $\mathrm{~B}_{\mathrm{SIZE}}$ & -0.113 & -0.476 \\
\hline $\mathrm{CEO}_{\mathrm{SEP}}$ & 0.359 & 0.332 & $\mathrm{CEO}_{\mathrm{SEP}}$ & -0.304 & -0.206 \\
\hline SIZE & 0.000 & 1.202 & SIZE & -0.000 & -0.005 \\
\hline ROA & 0.002 & 0.245 & ROA & -0.187 & -0.479 \\
\hline DEBT & -0.688 & -0.798 & DEBT & -0.000 & -0.023 \\
\hline$R^{2}$ & \multicolumn{2}{|l|}{0.108} & $R^{2}$ & \multicolumn{2}{|c|}{0.058} \\
\hline Chi-Square & \multicolumn{2}{|c|}{$41.835^{* * *}$} & F statistic & \multicolumn{2}{|c|}{$5.985^{* * *}$} \\
\hline Firm-effect & \multicolumn{2}{|c|}{ Included } & Firm-effect & \multicolumn{2}{|c|}{ Included } \\
\hline Year-effect & \multicolumn{2}{|c|}{ Included } & Year-effect & \multicolumn{2}{|c|}{ Included } \\
\hline Hausman Test & \multicolumn{2}{|c|}{8.5701} & Hausman Test & \multicolumn{2}{|c|}{$113.44^{* * *}$} \\
\hline Type of panel data & \multicolumn{2}{|c|}{ Random } & Type of panel data & Fixe & \\
\hline LBI test & 1.88 & & LBI test & 1.5 & \\
\hline
\end{tabular}

Note: ${ }^{*}$ Correlation was significant at the 0.1 level (2-tailed), ${ }^{* *}$ Correlation was significant at the 0.05 level (2-tailed), $* * *$ Correlation was significant at the 0.01 level (2-tailed).

Table 8. Results of the regression model by country with the environmental score as the dependent variable. Source: Authors.

\begin{tabular}{|c|c|c|c|c|c|}
\hline \multicolumn{3}{|c|}{$\begin{array}{c}\text { Dependent Variable: Environmental } \\
\text { Score-Spain }\end{array}$} & \multicolumn{3}{|c|}{$\begin{array}{l}\text { Dependent Variable: Environmental } \\
\text { Score-Germany }\end{array}$} \\
\hline Variable & $\begin{array}{c}\text { Standardized } \\
\text { Coefficients }(\beta)\end{array}$ & $t$ & Variable & $\begin{array}{l}\text { Standardized } \\
\text { Coefficients }(\beta)\end{array}$ & $t$ \\
\hline $\mathrm{CSR}_{\mathrm{COM}}$ & 7.953 & $5.117^{* * *}$ & $\mathrm{CSR}_{\mathrm{COM}}$ & 5.178 & $2.431 * *$ \\
\hline $\mathrm{B}_{\mathrm{IND}}$ & 0.105 & $1.846^{*}$ & $\mathrm{~B}_{\mathrm{IND}}$ & -0.042 & -1.238 \\
\hline $\mathrm{B}_{\mathrm{NEM}}$ & -0.382 & $-3.567 * * *$ & $\mathrm{~B}_{\mathrm{NEM}}$ & -0.215 & -0.786 \\
\hline $\mathrm{B}_{\mathrm{SIZE}}$ & 1.041 & $2.762 * * *$ & $\mathrm{~B}_{\text {SIZE }}$ & 0.467 & 0.889 \\
\hline $\mathrm{CEO}_{\mathrm{SEP}}$ & 1.305 & 0.675 & $\mathrm{CEO}_{\mathrm{SEP}}$ & -2.998 & -0.956 \\
\hline SIZE & 0.000 & 1.566 & SIZE & 0.000 & 1.760 * \\
\hline ROA & 0.305 & $2.680^{* * *}$ & ROA & -0.377 & -1.486 \\
\hline DEBT & -0.080 & -0.221 & DEBT & 0.424 & 0.965 \\
\hline$R^{2}$ & \multicolumn{2}{|l|}{0.160} & $R^{2}$ & \multicolumn{2}{|l|}{0.113} \\
\hline
\end{tabular}


Table 8. Cont.

\begin{tabular}{|c|c|c|c|c|c|}
\hline Chi-Square & \multicolumn{2}{|c|}{$40.101^{* * *}$} & F statistic & \multicolumn{2}{|c|}{$2.786^{* * *}$} \\
\hline Firm-effect & \multicolumn{2}{|c|}{ Included } & Firm-effect & \multicolumn{2}{|c|}{ Included } \\
\hline Year-effect & \multicolumn{2}{|c|}{ Included } & Year-effect & \multicolumn{2}{|c|}{ Included } \\
\hline Hausman Test & \multicolumn{2}{|c|}{8.948} & Hausman Test & \multicolumn{2}{|c|}{$9914.1^{* * *}$} \\
\hline Type of panel data & \multicolumn{2}{|c|}{ Random } & Type of panel data & \multicolumn{2}{|c|}{ Fixed } \\
\hline LBI test & \multicolumn{2}{|c|}{1.67} & LBI test & \multicolumn{2}{|c|}{1.62} \\
\hline \multicolumn{3}{|c|}{$\begin{array}{l}\text { Dependent Variable: Environmental } \\
\text { Score-France }\end{array}$} & \multicolumn{3}{|c|}{ Dependent Variable: Environmental Score-UK } \\
\hline Variable & $\begin{array}{c}\text { Standardized } \\
\text { Coefficients }(\beta)\end{array}$ & $t$ & Variable & $\begin{array}{c}\text { Standardized } \\
\text { Coefficients }(\beta)\end{array}$ & $t$ \\
\hline $\mathrm{CSR}_{\mathrm{COM}}$ & 4.132 & $5.031^{* * *}$ & $\mathrm{CSR}_{\mathrm{COM}}$ & 8.647 & $7.810^{* * *}$ \\
\hline $\mathrm{B}_{\mathrm{IND}}$ & -0.060 & $-2.317^{* *}$ & $\mathrm{~B}_{\mathrm{IND}}$ & 0.074 & $1.911 *$ \\
\hline $\mathrm{B}_{\mathrm{NEM}}$ & -0.041 & -0.972 & $\mathrm{~B}_{\mathrm{NEM}}$ & -0.001 & -0.018 \\
\hline $\mathrm{B}_{\mathrm{SIZE}}$ & 0.155 & 0.913 & $\mathrm{~B}_{\mathrm{SIZE}}$ & 0.894 & 3.398 \\
\hline $\mathrm{CEO}_{\mathrm{SEP}}$ & 0.487 & 0.509 & $\mathrm{CEO}_{\mathrm{SEP}}$ & -1.62 & -1.002 \\
\hline SIZE & 0.000 & 0.051 & SIZE & -0.000 & $-0.234^{* * *}$ \\
\hline $\mathrm{ROA}$ & 0.008 & 1.113 & $\mathrm{ROA}$ & -0.060 & -1.418 \\
\hline DEBT & -0.372 & -0.473 & DEBT & 0.006 & 0.219 \\
\hline$R^{2}$ & \multicolumn{2}{|c|}{0.129} & $R^{2}$ & \multicolumn{2}{|c|}{0.102} \\
\hline Chi-Square & \multicolumn{2}{|c|}{$50.481 * * *$} & F statistic & \multicolumn{2}{|c|}{$11.13^{* * *}$} \\
\hline Firm-effect & \multicolumn{2}{|c|}{ Included } & Firm-effect & \multicolumn{2}{|c|}{ Included } \\
\hline Year-effect & \multicolumn{2}{|c|}{ Included } & Year-effect & \multicolumn{2}{|c|}{ Included } \\
\hline Hausman Test & \multicolumn{2}{|c|}{12.541} & Hausman Test & \multicolumn{2}{|c|}{$80.561^{* * *}$} \\
\hline Type of panel data & \multicolumn{2}{|c|}{ Random } & Type of panel data & \multicolumn{2}{|c|}{ Fixed } \\
\hline LBI test & \multicolumn{2}{|c|}{1.92} & LBI test & \multicolumn{2}{|c|}{1.49} \\
\hline
\end{tabular}

Note: * Correlation was significant at the 0.1 level (2-tailed), ${ }^{* *}$ Correlation was significant at the 0.05 level (2-tailed), *** Correlation was significant at the 0.01 level (2-tailed).

Table 9. Results of the regression model by country with the corporate governance score as the dependent variable. Source: Authors.

\begin{tabular}{|c|c|c|c|c|c|}
\hline \multicolumn{3}{|c|}{$\begin{array}{c}\text { Dependent Variable: Corporate Governance } \\
\text { Score-Spain }\end{array}$} & \multicolumn{3}{|c|}{$\begin{array}{l}\text { Dependent Variable: Corporate Governance } \\
\text { Score-Germany }\end{array}$} \\
\hline Variable & $\begin{array}{c}\text { Standardized } \\
\text { Coefficients }(\beta)\end{array}$ & $t$ & Variable & $\begin{array}{c}\text { Standardized } \\
\text { Coefficients }(\beta)\end{array}$ & $t$ \\
\hline $\mathrm{CSR}_{\mathrm{COM}}$ & 11.792 & $6.223 * * *$ & $\mathrm{CSR}_{\mathrm{COM}}$ & 8.467 & $3.090^{* * *}$ \\
\hline $\mathrm{B}_{\mathrm{IND}}$ & 0.050 & 0.719 & $\mathrm{~B}_{\mathrm{IND}}$ & 0.013 & 0.302 \\
\hline $\mathrm{B}_{\mathrm{NEM}}$ & -0.24 & -1.898 & $\mathrm{~B}_{\mathrm{NEM}}$ & 0.204 & 0.580 \\
\hline $\mathrm{B}_{\mathrm{SIZE}}$ & 0.065 & 0.141 * & $\mathrm{B}_{\mathrm{SIZE}}$ & 0.692 & 1.024 \\
\hline $\mathrm{CEO}_{\mathrm{SEP}}$ & -0.057 & -0.024 & $\mathrm{CEO}_{\mathrm{SEP}}$ & 1.437 & 0.356 \\
\hline SIZE & 0.000 & $2.09 * *$ & SIZE & 0.000 & 1.713 * \\
\hline $\mathrm{ROA}$ & -0.002 & -0.016 & ROA & -0.137 & -0.420 \\
\hline DEBT & 0.527 & 1.084 & DEBT & -0.018 & -0.032 \\
\hline$R^{2}$ & \multicolumn{2}{|c|}{0.161} & $R^{2}$ & \multicolumn{2}{|c|}{0.105} \\
\hline Chi-Square & \multicolumn{2}{|c|}{$44.405 * * *$} & Chi-Square & \multicolumn{2}{|c|}{$2.568^{* *}$} \\
\hline Firm-effect & \multicolumn{2}{|c|}{$\mathrm{dw}$} & Firm-effect & \multicolumn{2}{|c|}{ Included } \\
\hline Year-effect & \multicolumn{2}{|c|}{ Included } & Year-effect & \multicolumn{2}{|c|}{ Included } \\
\hline Hausman Test & \multicolumn{2}{|c|}{1.559} & Hausman Test & \multicolumn{2}{|c|}{$50.516^{* * *}$} \\
\hline Type of panel data & \multicolumn{2}{|c|}{ Random } & Type of panel data & \multicolumn{2}{|c|}{ Fixed } \\
\hline LBI test & \multicolumn{2}{|c|}{2.01} & LBI test & \multicolumn{2}{|c|}{1.62} \\
\hline \multicolumn{3}{|c|}{$\begin{array}{c}\text { Dependent Variable: Corporate Governance } \\
\text { Score-France }\end{array}$} & \multicolumn{3}{|c|}{$\begin{array}{c}\text { Dependent Variable: Corporate Governance } \\
\text { Score-UK }\end{array}$} \\
\hline Variable & $\begin{array}{l}\text { Standardized } \\
\text { Coefficients }(\beta)\end{array}$ & $t$ & Variable & $\begin{array}{c}\text { Standardized } \\
\text { Coefficients }(\beta)\end{array}$ & $t$ \\
\hline $\mathrm{CSR}_{\mathrm{COM}}$ & 12.843 & $8.135^{* * *}$ & $\mathrm{CSR}_{\mathrm{COM}}$ & 6.811 & $6.997^{* * *}$ \\
\hline $\mathrm{B}_{\mathrm{IND}}$ & 0.103 & $2.067^{* *}$ & $\mathrm{~B}_{\mathrm{IND}}$ & 0.073 & $2.140 * *$ \\
\hline
\end{tabular}


Table 9. Cont.

\begin{tabular}{|c|c|c|c|c|c|}
\hline $\mathrm{B}_{\mathrm{NEM}}$ & 0.0783 & 0.950 & $\mathrm{~B}_{\mathrm{NEM}}$ & 0.040 & 0.778 \\
\hline $\mathrm{B}_{\mathrm{SIZE}}$ & -0.114 & -0.353 & $\mathrm{~B}_{\mathrm{SIZE}}$ & 0.441 & $1.910 *$ \\
\hline $\mathrm{CEO}_{\mathrm{SEP}}$ & -2.163 & -1.179 & $\mathrm{CEO}_{\mathrm{SEP}}$ & -3.513 & $-2.464^{* *}$ \\
\hline SIZE & 0.000 & 0.952 & SIZE & 0.000 & 0.425 \\
\hline ROA & 0.014 & 0.706 & $\mathrm{ROA}$ & -0.019 & -0.511 \\
\hline DEBT & -0.807 & -0.538 & DEBT & 0.011 & 0.478 \\
\hline$R^{2}$ & \multicolumn{2}{|c|}{0.188} & $R^{2}$ & \multicolumn{2}{|c|}{0.091} \\
\hline Chi-Square & \multicolumn{2}{|c|}{$80.054 * * *$} & Chi-Square & \multicolumn{2}{|c|}{$9.768^{* * *}$} \\
\hline Firm-effect & \multicolumn{2}{|c|}{ Included } & Firm-effect & \multicolumn{2}{|c|}{ Included } \\
\hline Year-effect & \multicolumn{2}{|c|}{ Included } & Year-effect & \multicolumn{2}{|c|}{ Included } \\
\hline Hausman Test & \multicolumn{2}{|c|}{12.849} & Hausman Test & \multicolumn{2}{|c|}{$38.941 * * *$} \\
\hline Type of panel data & \multicolumn{2}{|c|}{ Random } & Type of panel data & \multicolumn{2}{|c|}{ Fixed } \\
\hline LBI test & \multicolumn{2}{|c|}{1.59} & LBI test & \multicolumn{2}{|c|}{1.72} \\
\hline
\end{tabular}

Note: * Correlation was significant at the 0.1 level (2-tailed), ${ }^{* *}$ Correlation was significant at the 0.05 level (2-tailed), ${ }^{* * *}$ Correlation was significant at the 0.01 level (2-tailed).

Table 10. Results of the regression model by country with the economic score as the dependent variable. Source: Authors.

\begin{tabular}{|c|c|c|c|c|c|}
\hline \multicolumn{3}{|c|}{ Dependent Variable: Economic Score-Spain } & \multicolumn{3}{|c|}{ Dependent Variable: Economic Score-Germany } \\
\hline Variable & $\begin{array}{l}\text { Standardized } \\
\text { Coefficients }(\beta)\end{array}$ & $t$ & Variable & $\begin{array}{c}\text { Standardized } \\
\text { Coefficients }(\beta)\end{array}$ & $t$ \\
\hline $\mathrm{CSR}_{\mathrm{COM}}$ & 2.522 & 1.116 & $\mathrm{CSR}_{\mathrm{COM}}$ & 13.646 & $4.954^{* * *}$ \\
\hline $\mathrm{B}_{\mathrm{IND}}$ & 0.159 & $1.811 *$ & $\mathrm{~B}_{\mathrm{IND}}$ & 0.030 & 0.687 \\
\hline $\mathrm{B}_{\mathrm{NEM}}$ & -0.578 & $-3.609 * * *$ & $\mathrm{~B}_{\mathrm{NEM}}$ & -0.367 & -0.955 \\
\hline $\mathrm{B}_{\mathrm{SIZE}}$ & 1.174 & $1.917^{*}$ & $\mathrm{~B}_{\mathrm{SIZE}}$ & -0.786 & $-1.732 *$ \\
\hline $\mathrm{CEO}_{\mathrm{SEP}}$ & 0.236 & 0.080 & $\mathrm{CEO}_{\mathrm{SEP}}$ & -1.113 & -0.306 \\
\hline SIZE & -0.000 & -0.135 & SIZE & 0.000 & $2.334^{* *}$ \\
\hline ROA & 0.645 & $3.879 * * *$ & ROA & 0.115 & 0.397 \\
\hline DEBT & 0.841 & 1.420 & DEBT & 0.146 & 0.264 \\
\hline$R^{2}$ & \multicolumn{2}{|c|}{0.131} & $R^{2}$ & \multicolumn{2}{|c|}{0.191} \\
\hline F statistic & \multicolumn{2}{|c|}{$3.923^{* * *}$} & F statistic & \multicolumn{2}{|c|}{$47.757^{* * *}$} \\
\hline Firm-effect & \multicolumn{2}{|c|}{ Included } & Firm-effect & \multicolumn{2}{|c|}{ Included } \\
\hline Year-effect & \multicolumn{2}{|c|}{ Included } & Year-effect & \multicolumn{2}{|c|}{ Included } \\
\hline Hausman Test & \multicolumn{2}{|c|}{$96.118^{* * *}$} & Hausman Test & \multicolumn{2}{|c|}{15.434} \\
\hline Type of panel data & \multicolumn{2}{|c|}{ Fixed } & Type of panel data & \multicolumn{2}{|c|}{ Random } \\
\hline LBI test & \multicolumn{2}{|c|}{1.71} & LBI test & \multicolumn{2}{|c|}{2.27} \\
\hline \multicolumn{3}{|c|}{ Dependent Variable: Economic Score-France } & \multicolumn{3}{|c|}{ Dependent Variable: Economic Score-UK } \\
\hline Variable & $\begin{array}{c}\text { Standardized } \\
\text { Coefficients }(\beta)\end{array}$ & $t$ & Variable & $\begin{array}{c}\text { Standardized } \\
\text { Coefficients }(\beta)\end{array}$ & $t$ \\
\hline $\mathrm{CSR}_{\mathrm{COM}}$ & 9.531 & $4.362 * * *$ & $\mathrm{CSR}_{\mathrm{COM}}$ & 10.226 & $5.312 * * *$ \\
\hline $\mathrm{B}_{\mathrm{IND}}$ & -0.084 & -1.161 & $\mathrm{~B}_{\mathrm{IND}}$ & 0.056 & 0.833 \\
\hline $\mathrm{B}_{\mathrm{NEM}}$ & -0.155 & -1.136 & $\mathrm{~B}_{\mathrm{NEM}}$ & 0.182 & $1.762 *$ \\
\hline $\mathrm{B}_{\mathrm{SIZE}}$ & 0.781 & 1.618 & $\mathrm{~B}_{\mathrm{SIZE}}$ & -0.367 & -0.804 \\
\hline $\mathrm{CEO}_{\text {SEP }}$ & -3.905 & -1.513 & $\mathrm{CEO}_{\mathrm{SEP}}$ & -5.841 & $-2.072 * *$ \\
\hline SIZE & -0.000 & $-2.080 * *$ & SIZE & 0.000 & 0.875 \\
\hline ROA & 0.401 & $1.939 *$ & ROA & -0.069 & -0.925 \\
\hline DEBT & -0.636 & -0.289 & DEBT & 0.009 & 0.197 \\
\hline$R^{2}$ & \multicolumn{2}{|c|}{0.103} & $R^{2}$ & \multicolumn{2}{|c|}{0.062} \\
\hline F statistic & \multicolumn{2}{|c|}{$4.406^{* * *}$} & F statistic & \multicolumn{2}{|c|}{$6.443^{* * *}$} \\
\hline Firm-effect & \multicolumn{2}{|c|}{ Included } & Firm-effect & \multicolumn{2}{|c|}{ Included } \\
\hline Year-effect & \multicolumn{2}{|c|}{ Included } & Year-effect & \multicolumn{2}{|c|}{ Included } \\
\hline Hausman Test & \multicolumn{2}{|c|}{$23.44^{* * *}$} & Hausman Test & \multicolumn{2}{|c|}{$28.085^{* * *}$} \\
\hline Type of panel data & \multicolumn{2}{|c|}{ Fixed } & Type of panel data & Fixe & \\
\hline LBI test & 1.8 & & LBI test & 1.5 & \\
\hline
\end{tabular}

Note: ${ }^{*}$ Correlation was significant at the 0.1 level (2-tailed), ${ }^{* *}$ Correlation was significant at the 0.05 level (2-tailed), *** Correlation was significant at the 0.01 level (2-tailed). 


\section{Discussion}

The creation of a CSR committee responds to practical reasons, delegating to experts the identification, management, and monitoring of sustainable issues. Although the creation of a CSR committee has not been institutionalized, various national structures such as governance codes or standards, or supranational structures such as institutions enhancing sustainability have proposed the convenience of a committee of this type within corporate governance.

This paper aimed to know whether the presence of a CSR committee affects the achievement of environmental, social, corporate governance (ESG), and economic scores. The mere fact of having a CSR committee favorably predisposes companies toward social responsibility and signal their concern for social issues, tending to be more transparent in CSR $[9,39,57]$ and monitor the adherence to adopted standards [38]. We obtained evidence that companies with CSR committees obtain significantly higher ESG and economic scores than companies without a CSR committee. This happened in the four considered countries: Spain, Germany, France, and the UK and for the four considered scores (excepting corporate governance in Germany), showing the balanced commitment of listed companies in the sample for all facets of social performance and sustainability. This is in line with [7], who posed that "these committees have multiple foci and it is most common for a committee to focus on two stakeholder groups at one" (p. 1181). However, non-significant differences in Germany may be due to the fact that it was the country with the lowest scores of corporate governance in the sample, which generated less differentiation among the companies. In addition, it was the only country in our sample with a mandatory two-tier corporate governance system. Although having a supervisory board may involve recognizing the vision of other stakeholders beyond shareholders, the fact is that Germany was the country in our sample with the highest percentage of companies with a CSR committee. This goes beyond the boundaries of our research objectives in this contribution, but implies the value companies give to sustainability (beyond corporate governance systems) and it is of sufficient interest to continue researching the relationship between the creation of expert committees and different governance systems.

Furthermore, carrying out the analyses with the disaggregation of the scores (environmental, social, corporate governance, and economic) enhances the line of research participated in by $[3,7,8]$, showing possible differences in the effect of the presence of a CSR committee. However, the effect in this case is quite homogeneous. In all countries and scores considered, the presence of a CSR committee positively affected the achievement of the consequent score (except for the economic score in Spain). Different components of social performance used in previous studies did not allow us to compare the results individually. However, those studies were performed in US companies, so we can say that the effect of CSR committees on non-financial performance can also be observed in European companies. The exception found in the relationship with the economic score in Spain also contributes to the heuristic of the CSR committees-financial performance relationship, where contradictory results have been traditionally raised. The authors in [3] also found a non-significant relationship between CSR committees and social scores. This led us to think about the importance of studies that consider CSR committees as mediators [58] in the relationships between corporate governance and corporate performance. The corporate governance system (one-tier, two-tier) and the way in which the company is managed and controlled could influence the willingness to address sustainability issues. In addition, the results related to the variables of control (independent and non-executive members in the board, size of the board, and CEO-Chairman separation) reflect the lack of a clear pattern in the effectiveness on non-financial performance. In this case, the type of corporate governance prevailing in each country could also be one of the explanatory factors. Thus, these results confirm that inquiring into the role of CSR committees and its interactions with other corporate governance structures is relevant and timely in a more demanding context in relation to sustainability, if organizations were to represent an important agent in leading, today, the achievement of sustainable development goals (SDGs).

One of the limitations of this study is precisely the scarce information on the CSR committee, having only the information regarding its presence or absence. It would have been interesting to have 
considered other characteristics such as its composition, size, objectives, or number of meetings. As a result, practitioners would know how to create and modulate CSR committees in order to improve performance effectiveness. In addition, the sample used may seem biased, since listed companies tend to have greater pressure to legitimize themselves in society. Being large companies, they also have more resources in their commitment to sustainability. However, the comparison in our study has been homogeneous and results have to serve as a benchmarking objective and encourage SMEs to integrate teams or committees responsible for social issues in order to enhance non-financial performance. To conclude, we should not fall into the error that the mere fact of having a specific committee devoted to ESG issues (understood as an item of a checklist) is going to boost non-financial performance. The creation of a new decision-making body implies increasing organizational efforts and also discrepancies, so the chances of diverting attention from the achievement of CSR objectives are increased. On the other hand, not having a CSR committee does not imply that companies do not perform CSR actions, since identifying and monitoring such actions may be the responsibility of some other member or structure in the organization. However, given the relevance that this committee has shown in the achievement of non-financial performance in our sample, from here we call for greater clarity on the part of those corporate governance and regulatory structures that recommend the existence of a CSR committee in a cursory manner, so that future recommendations and guidelines should highlight the creation of structures that promote its internalization and significance in corporate governance.

\section{Conclusions}

CSR committees emerge to assist corporate boards in social and sustainability issues. Although the existence of such committees has been mainly related to the quantity and quality of CSR/ESG disclosure, the effect on corporate social performance (CSP) or non-financial performance has been focused on US-based samples. This contribution is relevant because we analyzed this relationship in the listed companies of four European countries, confirming the effectiveness of CSR committees in several components of non-financial performance, in line with previous studies having disaggregated CSp. In addition, we have shown that companies with a CSR committee show significantly greater non-financial performance. Despite having analyzed a sample of large companies in only four European countries, we must avoid falling into the trap of generalizing that only CSR committees can enhance non-financial performance. In this sense, a CSR director or a CSR specialist, integrated into some other group and not a specific CSR committee, could also influence non-financial performance. As a result of this study, we can extract practical implications for companies. The first of these would be to recommend the creation of efficient participatory bodies. Increasing the participation and presence of stakeholders, as indicated by stakeholder theory, shows a clear predisposition of the company to meet the needs of all stakeholders and greater transparency in its actions. According to the results obtained, we can say that CSR committees are an example of these efficient participatory bodies, since they transmit and ensure the social concerns of all stakeholders, and show a greater predisposition to compliance with social principles and the adoption of global standards. Second, it can be said that the creation of CSR committees, understood as voluntarily constituted bodies, will show a greater social predisposition of companies in countries that lack strict CSR governance codes and no specific references to corporate social responsibility and the audit of social information. Our results can also serve as a guide for small and medium-sized enterprises (SMEs) that want to implement sustainable policies, knowing that a CSR committee controls, monitors, and promotes sustainable behavior.

Author Contributions: Conceptualization, E.B.-D. and M.D.O.; Formal analysis, E.B.-D.; Investigation, E.B.-D. and M.D.O.; Methodology, E.B.-D. and M.D.O.; Software, E.B.-D.; Supervision, E.B.-D.; Writing-Original draft, E.B.-D.; Writing-Review \& editing, E.B.-D. and M.D.O.

Funding: This research received no external funding

Conflicts of Interest: The authors declare no conflict of interest 


\section{References}

1. Adnan, S.M.; Hay, D.; van Staden, C.J. The influence of culture and corporate governance on corporate social responsibility disclosure: A cross country analysis. J. Clean. Prod. 2018, 198, 820-832. [CrossRef]

2. Oh, W.Y.; Chang, Y.K.; Kim, T.Y. Complementary or substitutive effects? Corporate governance mechanisms and corporate social responsibility. J. Manag. 2018, 44, 1739-2716. [CrossRef]

3. Hussain, N.; Rigoni, U.; Orij, R.p. Corporate Governance and Sustainability Performance. Analysis of Triple Bottom Line Performance. J. Bus. Ethics 2018, 149, 411-432. [CrossRef]

4. Giannarakis, G. Corporate governance and financial characteristics effects on the extent of corporate social responsibility disclosure. Soc. Responsib. J. 2014, 10, 569-590. [CrossRef]

5. Mackenzie, C. Boards, Incentives and Corporate Social Responsibility: The case for a change of emphasis. Corp. Gov. Int. Rev. 2007, 15, 935-943. [CrossRef]

6. Gennari, F.; Salvioni, D.M. CSR committees on boards: The impact of the external country level factors. J. Manag. Gov. 2018, 23, 1-27. [CrossRef]

7. Burke, J.J.; Hoitash, R.; Hoitash, U. The Heterogeneity of Board-Level Sustainability Committees and Corporate Social Performance. J. Bus. Ethics 2019, 154, 1161-1186. [CrossRef]

8. Mallin, C.A.; Michelon, G. Board reputation attributes and corporate social performance: An empirical investigation of the US Best Corporate Citizens. Account. Bus. Res. 2011, 41, 119-144. [CrossRef]

9. Zahra, S.A. Boards of directors and corporate social responsibility performance. Eur. Manag. J. 1989, 7, 240-247.

10. Mallin, C.; Michelon, G.; Raggi, D. Monitorin Intensity and Stakeholders' Orientation: How Does Governance Affect Social and Environmental Disclosure? J. Bus. Ethics 2013, 114, 29-43. [CrossRef]

11. Velte, p. Women on management board and ESG performance. J. Glob. Responsib. 2016, 7, 98-109. [CrossRef]

12. Jo, H.; Harjoto, M.A. The causal effect of corporate governance on corporate social responsibility. J. Bus. Ethics 2011, 106, 53-72. [CrossRef]

13. Walls, J.L.; Berrone, P.; Phan, P.H. Corporate governance and environmental performance: Is there really a link? Strateg. Manag. J. 2012, 33, 885-913. [CrossRef]

14. Fuente, J.A.M.; García-Sánchez, I.M.; Lozano, M.B. The role of the board of directors in the adoption of GRI guidelines for the disclosure of CSR information. J. Clean. Prod. 2017, 141, 737-750. [CrossRef]

15. Ienciu, I.A.; Popa, I.E.; Ienciu, N.M. Environmental reporting and good practice of corporate governance: Pretroleum industry case study. Procedia Econ. Financ. 2014, 3, 961-967. [CrossRef]

16. Adel, C.; Hussain, M.M.; Mohammed, E.K.A.; Basuony, M.A.K. Is Corporate governance relevant to the quality of corporate social responsibility disclosure in large European companies? Int. J. Account. Inf. Manag. 2019, 27, 301-332. [CrossRef]

17. Awodiran, M.A. Corporate Govenance and Sustainability Disclosure: Evidence from Listed Industrial Goods Firms in Nigeria. J. Econ. Manag. Soc. Sci. 2019, 5, 67-82.

18. Shwairef, A.; Amran, A.; Iranmanesh, M. The mediating effect of strategic posture on corporate governance and environmental reporting. Rev. Manag. Sci. 2019. [CrossRef]

19. Cucari, N.; Esposito de Falco, S.; Orlando, B. Diversity of board of directors and environmental social governance: Evidence from Italian listed companies. Corp. Soc. Responsib. Environ. Manag. 2018, 25, 250-266. [CrossRef]

20. Eberhardt-Toth, E. Who should be on a board corporate responsibility committee? J. Clean. Prod. 2017, 140, 1926-1935. [CrossRef]

21. Raghunathan, M.; Kumar, A. CSR Committee Composition and Possible Impacts. J. Contemp. Res. Manag. 2018, 13, 9-27.

22. Danvila, I.; Díez, J.M.; López, O. Corporate social responsibility and sustainability committee inside the board. Eur. J. Int. Manag. 2019, 13, 159-176. [CrossRef]

23. Birindelli, G.; Dell'Atti, S.; Iannuzzi, A.; Savioli, M. Composition and Activity of the Board of Directors: Impact on ESG Performance in the Banking System. Sustainability 2018, 10, 4699. [CrossRef]

24. Baraibar-Diez, E.; Odriozola, M.D.; Fernández Sánchez, J.L. Sustainable Compensation policies and its effect on environmental, social, and governance scores. Corp. Soc. Responsib. Environ. Manag. 2019. [CrossRef]

25. Flammer, C. Does product market competition foster corporate social responsibility? Evidence from trade liberalization. Strateg. Manag. J. 2014, 36, 1469-1485. [CrossRef] 
26. Shaukat, A.; Qi, Y.; Trojanowski, G. Board Attributes, Corporate Social Responsibility Strategy, and Corporate Environmental and Social Performance. J. Bus. Ethics 2016, 135, 569-585. [CrossRef]

27. Donaldson, T.; Preston, L.E. The stakeholder theory of the corporation: Concepts, evidence, and implications. Acad. Manag. Rev. 1995, 20, 65-91. [CrossRef]

28. CNMV. Good Governance Code of Listed Companies 2015 Spanish Stock Market Commission. Available online: http://www.cnmv.es/DocPortal/Publicaciones/CodigoGov/Good_Governanceen.pdf (accessed on 20 June 2019).

29. Regierungskommission. German Corporate Governance Code 2017. Available online: https://dcgk.de/en/ home.html (accessed on 20 June 2019).

30. Ferreira, D.; Kirchmaier, T. Corporate boards in Europe: Size, independence and gender diversity. In Boards and Shareholders in European Listed Companies: Facts, Context and Post-Crisis Reforms. International Corporate Law and Financial Market Regulation; Belcredi, M., Ferrarini, G., Eds.; Cambridge University Press: Cambridge, UK, 2013; pp. 191-224.

31. Block, D.; Gerstner, A.M. One-Tier vs Two-Tier Board Structure: A Comparison between the United States and Germany. Comparative Corporate Governance and Financial Regulation, Paper 1. 2016. Available online: https://scholarship.law.upenn.edu/fisch_2016/1/ (accessed on 20 June 2019).

32. Hopt, K.; Patrick, L. Board Models in Europe-Recent Developments of Internal Corporate Governance Structures in Germany, the United Kingdom, France and Italy. Eur. Co. Financ. Law Rev. 2004, 1, 135-168.

33. Panwar, R.; Nawani, S.; Pandey, V. Legislated CSR: A Brief Introduction. In Corporate Social Responsibility; Business and Society 360; Emerald Publishing Limited: Bingley, UK, 2018; Volume 2, pp. 133-146.

34. International Institute for Sustainable Development (IISD). Corporate Social Responsibility. An Implementation Guide for Business. 2007. Available online: https://www.iisd.org/pdf/2007/csr_guide.pdf (accessed on 20 June 2019).

35. CSR Europe. New Version of SGE 21 Standard form Forética: An Ethical and Socially Responsible Management System for Companies and Organisations. Available online: https://www.csreurope.org/new-version-sge-21-standard-for\%C3\%A9tica-ethical-and-sociallyresponsible-management-system-companies\#.XLzFrOgzZPY (accessed on 20 June 2019).

36. Forética. SGE 21. Sistema de Gestión Ética y Socialmente Responsible. 2017. Available online: http: //www.foretica.org/norma_SGE_21.pdf (accessed on 20 June 2019).

37. Altschuller, S.A. Board Oversight of CSR \& the Role of the CSR Committee. Corporate Social Responsibility and the Law. 2013. Available online: https://www.csrandthelaw.com/2013/03/11/board-oversight-of-csr-therole-of-the-csr-committee/ (accessed on 20 June 2019).

38. Arjalies, D.L.; Mundy, J. The use of management control systems to manage CSR strategy: A levers of control perspective. Manag. Account. Res. 2013, 24, 284-300. [CrossRef]

39. Cowen, S.S.; Ferreri, L.B.; Parker, L.D. The impact of corporate characteristics on social responsibility disclosure: A typology and frequency-based analysis. Account. Organ. Soc. 1987, 12, 111-122. [CrossRef]

40. Roberts, R.W. Determinants of corporate social responsibility disclosure: An application of stakeholder theory. Account. Organ. Soc. 1992, 17, 595-612. [CrossRef]

41. Gray, R.; Kouhy, R.; Lavers, S. Corporate social and environmental reporting: A review of the literature and a longitudinal study of UK disclosure. Account. Audit. Account. J. 1995, 8, 47-77. [CrossRef]

42. Alnajjar, F.K. Determinants of social responsibility disclosures of US Fortune 500 firms: An application of content analysis. In Advances in Environmental Accounting \& Management; Emerald Group Publishing Limited: Bingley, UK, 2000; pp. 163-200.

43. World Bank Data. GDP (Current US\$). World Bank National Accounts Data, and OECD National Accounts Data Files (Time Series). 2019. Available online: https://data.worldbank.org/indicator/NY.GDP.MKTP.CD? locations=ES-GB-FR-DE-IT (accessed on 1 August 2019).

44. World Bank Data. Market Capitalization of Listed Domestic Companies (\% of GDP). World Federation of Exchanges Database (Time Series). 2019. Available online: https://data.worldbank.org/indicator/CM.MKT. LCAP.GD.ZS?locations=ES-GB-FR-DE-IT (accessed on 1 August 2019).

45. Croissant, Y.; Millo, G.; Tappe, K.; Toomet, O.; Kleiber, C.; Zeileis, A. Package “plm”. Choice 2017, 139, 227-240.

46. Cheng, B.; Ioannou, I.; Serafeim, G. Corporate social responsibility and access to finance. Strateg. Manag. J. 2014, 35, 1-23. [CrossRef] 
47. Taliento, M.; Favino, C.; Netti, A. Impact of Environmental, Social, and Governance Information on Economic Performance: Evidence of a Corporate 'Sustainability Advantage' from Europe. Sustainability 2019, 11, 1738. [CrossRef]

48. Miralles-Quirós, M.M.; Miralles-Quirós, J.L.; Redondo Hernández, J. ESG Performance and Shareholder Value Creation in the Banking Industry: International Differences. Sustainability 2019, 11, 1404. [CrossRef]

49. Thomson Reuters. Asset4 ESG data glossary in Datastream; Thomson Reuters: Toronto, ON, Canada, 2017.

50. Isidro, H.; Sobral, M. The Effects of Women on Corporate Boards on Firm Value, Financial Performance, and Ethical and Social Compliance. J. Bus. Ethics 2015, 132, 1-19. [CrossRef]

51. Mahoney, L.; Thorne, L. An examination of the structure of executive compensation and corporate social responsibility: A Canadian investigation. J. Bus. Ethics 2006, 69, 149-162. [CrossRef]

52. Haque, F. The effects of board characteristics and sustainable compensation policy on carbon performance of UK firms. Br. Account. Rev. 2017, 49, 347-364. [CrossRef]

53. Habbash, M. Corporate governance, ownership, company structure and environmental disclosure: Evidence from Saudi Arabia. J. Gov. Regul. 2015, 4, 460-470. [CrossRef]

54. Cai, Y.; Jo, H.; Pan, C. Vice or virtue? The impact of corporate social responsibility on executive compensation. J. Bus. Ethics 2011, 104, 159-173. [CrossRef]

55. Baltagi, B.H.; Wu, P.X. Unequally spaced panel data regressions with AR(1) disturbances. Econom. Theory 1999, 15, 814-823. [CrossRef]

56. Aupperle, K.E.; Carroll, A.B.; Hatfield, J.D. An Empirical Examination of the Relationship between Corporate Social Responsibility and Profitability. Acad. Manag. J. 1985, 28, 446-463.

57. Adams, C. Internal organizational factors influencing corporate social and ethical reporting: Beyond current theorizing. Account. Audit. Account. J. 2002, 30, 1-21.

58. García-Sánchez, I.M.; Gómez-Miranda, M.E.; David, F.; Rodríguez-Ariza, L. Board Independence and GRI-IFC performance standards: The mediating effect of the CSR committee. J. Clean. Prod. 2019, 225, 554-562. [CrossRef]

(C) 2019 by the authors. Licensee MDPI, Basel, Switzerland. This article is an open access article distributed under the terms and conditions of the Creative Commons Attribution (CC BY) license (http://creativecommons.org/licenses/by/4.0/). 